\title{
Den kloge godsforvalter (Luk 16,1-8a)
}

\author{
Jødisk pagtsnomisme som nøgle til lignelsen i \\ Lukasevangeliets fortælleforløb
}

\author{
Lektor, ph.d. \\ Kasper Bro Larsen
}

\begin{abstract}
The parable of the prudent manager in Luke 16:1-8a constitutes an exegetical puzzle. The present article understands the parable in light of early Jewish covenantal nomism (E.P. Sanders). The parable is not a theological replica of "The Prodigal Son" (pace J.R. Donahue) but a sequel to that story. Whereas "The Prodigal Son" tells a story to outsiders of getting in, "The Prudent Manager" narrates to insiders a story about staying in. The manager first foolishly squanders his master's possessions (v. 1b-3); but in the face of crisis, he acts generously in the interest of others (vv. 4-7) and is praised for being prudent (v. 8a). The manager thus personifies "the faithful and prudent manager" mentioned in Luke 12:43. He is an example for disciples to follow. Occasioned by the 75th anniversary of academic theology at Aarhus University, the article begins with a review of 20th century dialectical-theological applications of the parable in the works of Professors K.E. Løgstrup, Regin Prenter, P.G. Lindhardt, and Johannes Sløk.
\end{abstract}

Keywords: Parable of the Dishonest Manager - Parable of the Unjust Steward - Luke 16:1-8a - covenantal nomism - covenantal soteriology - E.P. Sanders - John R. Donahue

\section{Indledning}

Jesu lignelse om den uærlige godsforvalter (ó oixovópos $\tau \tilde{\eta} \varsigma$ ảdxías), som den kaldes i den autoriserede danske oversættelse (DO92), har siden oldkirken været lignelseseksegesens smertensbarn. ${ }^{1}$ Fortællingen om forvalteren, der får ros på trods af sit angiveligt umoralske levned,

1. Se beskrivelsen hos Adolf Jülicher, grundlæggeren af den moderne lignelseseksegese, i hans Die Gleichnisreden Jesu (Tübingen: Mohr Siebeck 1910), 2.495. For forskningshistoriske oversigter se Dennis J. Ireland, "A History of Recent Interpretation of the Parable of the Unjust Steward (Luke 16:1-13)", Westminster Theological Journal 51 (1989), 293-318 og David Landry \& Ben May, "Honor Restored: New Light on the Parable of the Prudent Steward (Luke 16:1-8a)", JBL 119 (2000), 287-309. For eksempler på lignelsens brug i teologihistorien, se François Bovon, Das Evangelium nach Lukas, EKK (Düsseldorf/Zürich: Benziger Verlag \& NeukirchenVluyn: Neukirchener Verlag 2001), 82-84. 
har forvirret læsere gennem kirkens historie - ja, måske endda Lukas selv - og heller ikke i bibelvidenskaben har der samlet sig en form for konsensus om, hvordan den skal forstås. Der er tale om en eksegetisk rorschachprøve, hvis fortolkning i særlig høj grad afhænger af den hermeneutiske ramme, som eksegeten placerer teksten i. Perikopen i Luk 16,1-13, der rummer lignelsen og et antal udlægninger af den, rejser således en lang række åbne spørgsmål: I hvilken forstand er godsforvalteren uretfærdig? Hvorfor roses han for sin klogskab? Er lignelsen ironisk? Hvornår slutter selve lignelsen, og hvor begynder dens udlægning? osv. Jeg skal ikke foregive, at den følgende artikel rummer den definitive fortolkning af en så vanskelig og omdiskuteret tekst som lignelsen her. Ikke desto mindre er der tale om et forsøg på en bedre forståelse af lignelsen i dens lukanske fortællesammenhæng og dens religionshistoriske kontekst i den tidlige jødedom, som kristusbevægelsen voksede frem i. Tesen er, at lignelsen hænger uløseligt sammen med den foregående lignelse i Luk 15 - ja, at den udgør en slags fortsættelse af lignelsen om den fortabte søn - således at de to lignelser tilsammen beskriver et jødisk pagtsnomistisk religionsnarrativ i lukaskristen aftapning ("pagtssoteriologi", se skemaet s. 183). Men som sagt viser receptionshistorien, at fortolkningsmulighederne er legio. Inden vi tager fat på den eksegetiske undersøgelse, skal vi foranlediget af aarhusteologiens 75-årsjubilæum kaste et blik på aktualiserende bibelbrug hos de fire "store" aarhusteologer, dvs. de fire professorer, der i den kirkelige og samfundsmæssige offentlighed tegnede aarhusteologiens grundlæggergeneration: K.E Løgstrup (1905-81), Regin Prenter (1907-90), P.G. Lindhardt (1910-88) og Johannes Sløk (1916-2001).

\section{Dialektisk-teologiske læsninger hos de "store" aarhusteologer ${ }^{2}$}

I Den Danske Folkekirke er lignelsen om den uærlige godsforvalter prædikentekst på niende søndag efter trinitatis efter første tekstrække (Luk 16,1-9). Eftersom de fire "store" aarhusteologer alle parallelt med det akademiske arbejde mere eller mindre hyppigt fungerede som prædikanter i folkekirken, var det særligt som sådan de kom til at brydes med lignelsen. Alle fire var præget af den dialektiske teologi, der anså det kristne budskab, ikke som garant for vestlig civilisation, sådan som liberalteologien og kulturprotestantismen optimistisk havde hævdet før Første Verdenskrig, men som et for mennesker radikalt

2. Tak til Carsten Bach-Nielsen, David Bugge og Kurt Ettrup Larsen for vejledning i litteraturfremskaffelse. I det følgende forholder jeg mig kun til udgivne tekster, ikke til hvad der måtte foreligge i efterladte arkiver. 
udefrakommende budskab. Evangeliet måtte derfor udmønte sig i kulturkritik, moralismekritik og i modsigelse af menneskelige ideologier og religiøse illusioner. Lignelsen om den uærlige godsforvalter blev hos alle fire aarhusteologer udlagt dialektisk-teologisk. Lad os se på de fire en for en.

Fra K.E. Løgstrups hånd foreligger der to prædikener holdt i løbet af dennes virke som sognepræst i Sandager-Holevad på Fyn (193643), dvs. fra før bruddet med Tidehverv i første halvdel af 1960'erne. Begge er udgivet posthumt. Prædikenen fra 1937 er mest interessant som reception af lignelsen. Den fremhæver det højst usædvanlige forhold i historien, at det er den svindelmistænkte forvalter selv, der sættes til at gøre regnskabet op. Den rige mands naivitet er åbenbart grænseløs. Løgstrup forstår dette som et billede på Gud som skaber, der på trods af menneskets egoisme bestandigt betror livet til sin skabning. Til denne originale skabelsesteologiske fortolkning føjes en antropologisk fortolkning af forvalteren som billede på menneskets altid mislykkede forsøg på moralsk og religiøs selvforbedring. Sidstnævnte udlægning er en mere konventionelt dialektisk-teologisk fortolkning, som vi også kan finde hos Lindhardt og Sløk. Evangeliet er, at mennesket ikke kan frelse sig selv: "Gud ske tak og lov for hans meget mærkelige evangelium til os i dag - der er lige så trøsterigt, som det er mærkeligt". ${ }^{3}$

Der foreligger ikke, så vidt jeg ved, nogen udgivet prædiken over teksten fra Regin Prenters side. Men Prenter skrev prædikenvejledning til teksten i Prasteforeningens Blad i 1949. Her samler interessen sig om at forstå udlægningen af lignelsen i vv. 8-9. Prenter går relativt eksegetisk til sagen, med henvisning til fx C.H. Dodds og Joachim Jeremias' nu klassiske lignelsesstudier, og forstår lignelsen i lyset af Jesu eskatologiske gudsrigesforkyndelse. Rigets umiddelbare nærhed betyder, at det nu gælder om - ligesom godsforvalteren - at give slip på alt, også den uærligt erhvervede mammon for at skaffe sig "venner", dvs. for at komme til at tilhøre Jesus og hans menighed. Afslutningsvis aktualiserer Prenter lignelsen på dialektisk-teologisk vis: "[O]gså denne muntre historie snerter, så det svider, til den nu almindelige borgerlige og kirkelige rigdom". ${ }^{4}$

3. K.E. Løgstrup, Pradikener fra Sandager-Holevad. red. Elsebeth Diderichsen og Ole Jensen (København: Gyldendal 1995), 58-61 (61). Prædikenen fra 1941 er mindre tekstnær, mere fænomenologisk og gentager kritikken af misforstået, livsforsagende religiøsitet (201-204).

4. Regin Prenter, “9. søndag efter Trinitatis. Luk. 16,1-9”, Presteforeningens Blad 39 (1949), 494-96 (496). Prenter var i øvrigt allerede i 1942 medudgiver af en samling prædikenvejledninger, blandt hvilke der også foreligger vejledning til denne tekst, men det fremgår ikke, i hvilket omfang Prenter bidrog til de enkelte vejled- 
P.G. Lindhardt var efterkrigstidens mest toneangivende prædikant i Danmark. Hans prædiken over Luk 16,1-9 ved Folketingets åbning d. 4. oktober 1960 er en luthersk tale om tro som tillid til Guds nåde og ikke som livsanskuelse. Lignelsen er et antropologisk spejl, der "viser os ikke nogle andre, men os selv, og siger det ... at fortabelse ikke er en af vore fremtidsmuligheder, men simpelt er at vi svindler med livet". ${ }^{5}$ Herrens ros til godsforvalteren forstås som bidende ironi, hvorved lignelsen kommer til at repræsentere loven i et luthersk lov/ evangelium-skema. Lignelsen afslører menneskets selviskhed (jf. lovens anden brug); og på den baggrund kan evangeliet om Guds nåde lyde. Til dagen henter Lindhardt det gode budskab i anden tekstrækkes prædikentekst (Luk 12,32). ${ }^{6}$

I Johannes Sløks forfatterskab behandles lignelsen ikke kun i prædikener, hvor tekstrækken har dikteret det, men også i flere af hans religionsfilosofiske bøger. Lignelsens barokke forløb tiltaler åbenbart absurdisten Sløk. Så vidt jeg kan se, diskuterer Sløk lignelsen første gang i en prædiken fra 1951 (posthumt udgivet i 2016), ifølge hvilken lignelsens paniske hovedperson sætter sin eksistens på spil "hinsides alle regler for moral og anstændighed". ${ }^{7}$ Prædikenen kan ses som en slags forstudie til Kristen moral for og nu fra 1959, hvor Sløk gik til angreb på sin samtids velbjærgede kristendom, som ifølge Sløk satte lighedstegn mellem Jesu budskab og borgerlig moralisme. Lignelsen udlægges i bogen som en blotlæggelse af menneskets desperate situation i eksistentiel forstand: "Man skal ikke forsøge at blive en bedragerisk godsforvalter, for i Jesu øjne er det just, hvad mennesket er" (Sløks kursiv). ${ }^{8}$ Mennesket er grundlæggende fortabt og kan kun som godsforvalteren desperat gribe efter udvej og mening. Som hos Løgstrup (delvist) og Lindhardt er udlægningen af lignelsen antropologisk. Hos 1980'ernes sene Sløk - efter hans sproglige og narrative Kehre - gentages denne udlægning af lignelsen, men nu med den

ninger. Se Johs. Asmund, Regin Prenter \& Paul Seidelin, Kirkeårets texter. Første textrakke: Trinitatistiden (København: Gads forlag 1942).

5. P.G. Lindhardt, "Troen”, Påskud og pradikener (København: Hans Reitzel 1963), 86-90 (88).

6. En senere prædiken over lignelsen holdt i 1982 er bygget over samme lutherske skema; se P.G. Lindhardt, 12 Pradikener (Aarhus: Aros 1984), 57-63. Der foreligger desuden en upubliceret prædiken fra 1975 efterladt i Lindhardts scrapbøger (SB. VI:82), jf. Ketil Boesen collab. Carsten Bach-Nielsen \& Knud Ottosen, Bibliografi over P.G. Lindhardts forfatterskab 1933-1980 (Aarhus: Kirkehistorisk Institut, Århus Universitet 1980).

7. Johannes Sløk, “9. søndag efter trinitatis, 1951. Lukasevangeliet kapitel 16, vers 1-9”, Liv og lidenskab. Efterladte og genfundne tekster udvalgt af Kjeld Holm (København: Kristeligt Dagblads Forlag 2016), 163-70 (169).

8. Johannes Sløk, Kristen moral for og nu (København: Hans Reitzel 1959), 63-64 (64). 
kristologiske tilføjelse, "at der er myte i den, at det derfor i en anden forstand er Jesus den handler om." " Lignelsen er med andre ord den kristne grundfortælling i en nøddeskal. Den handler om Kristus som ham, der i stedet for at paralyseres over menneskets meningsløse situation svarer på den med en ødsel rundhåndethed, der må tage sig ud som bedrageri og svindel for det menneskelige blik: "I den desperate situation er frelsen en ny desperat handling, thi at blive kristen er at følge Kristus efter ved at lade hans historie gælde som min" (ibid.).

Som det ses af ovenstående, deler de fire "store" aarhusteologer en fælles dialektisk-teologisk forudsætning i deres udlægning af Luk 16,1-9. Lignelsen tolkes som en provokation eller en forargelse for det selvforsikrende menneske og herigennem til ny opbyggelse. Den antropologiske fortolkning, ifølge hvilken lignelsen udgør et portræt af mennesket som moralsk og eksistentiel svindler, er gennemgående hos Løgstrup, Sløk og Lindhardt, hos sidstnævnte dog mere eksplicit luthersk udtrykt end hos de øvrige. Prenters fortolkning er eskatologisk og handler om omvendelsens nødvendighed. Endelig foretager den tidlige Løgstrup en skabelsesteologisk fortolkning og den sene Sløk en kristologisk. For alle fire teologiprofessorers vedkommende er der vel at mærke tale om aktualiserende bibelbrug i form af prædiken, prædikenvejledning eller religionsfilosofi, ikke historisk-eksegetisk fortolkning. Det er vigtigt, at holde sig forskellen på disse to bestræbelser for øje (hhv. aktualiserende brug og historisk fortolkning) - i den første bestræbelse er den til enhver tid aktuelle kontekst udgangspunkt for anvendelsen af teksten; i den anden er den rekonstruerede historiske kontekst bestemmende. Efter min mening kan den ene hermeneutiske genre hverken verificere eller falsificere den anden, men der kan være tale om indbyrdes inspiration. Det følgende repræsenterer som sagt en historisk-eksegetisk fortolkning af lignelsen. ${ }^{10}$

\section{Den tidlige jødedoms pagtsnomisme som lignelsens religionshistoriske kontekst}

Som vi allerede har set, gælder det ikke mindst for denne lignelse, at dens fortolkning afhænger af, hvilken kontekst man holder den op imod. I eksegesen har diskussionen ofte drejet sig om lignelsens be-

9. Johannes Sløk, Da Gud fortalte en historie (Aarhus: Centrum 1985), 125.

10. For diskussion af distinktionen mellem brug og fortolkning se Geert Hallbäck, "Hvad er reception?" Collegium Biblicums Årsskrift (2006), 7-22, jf. Umberto Eco, The Limits of Interpretation, Advances in Semiotics (Bloomington: Indiana University Press 1990), 44-63. 
tydning i den historiske Jesus' gudrigesforkyndelse, enten som eskatologisk kald til omvendelse, som kritik af religiøse autoriteter, som socio-økonomisk protestråb eller i en kombination af disse betydninger. Med andre ord opfattes lignelsen som en fortælling, der i den ene eller anden form går tilbage til Jesus selv. ${ }^{11}$ Det, der skal interessere os her, er imidlertid ikke en mulig førlukansk traditionshistorie og dens forhold til den lukanske redaktion, men lignelsens betydning internt i Lukasevangeliets narrative univers (den intratekstuelle kontekst) og i lyset af samtidens jødiske teologi (den religionshistoriske kontekst).

Lad os begynde med at indkredse den religionshistoriske kontekst. Ligesom de øvrige nytestamentlige tekster foregår lignelsen i den tidlige jødedoms teologiske univers. I nyere tid er det særligt E.P. Sanders (skønt han havde forløbere), som har reformeret eksegeternes syn på den tidlige jødedom. Det skete i særdeleshed med bogen Paul and Palestinian Judaism fra 1977. Bogen var et opgør med det billede af jødedommen, som særligt florerede i protestantisk eksegese og teologi. Her beskrev man jødedommen på Jesu tid som en legalisme, hvor Guds nåde skulle fortjenes gennem minutiøs overholdelse af overfladiske forskrifter og ritualer, med andre ord som en degenereret og forstenet udgave af gammeltestamentlig religion. Og, mente man, det var alt dette, Jesus gjorde op med. Men dette billede af jødedommen, hævdede Sanders, var en fatal karikatur og en anakronisme. I stedet for at prøve at forstå den tidlige jødedom på sine egne præmisser havde man reelt gjort Luthers opgør med middelalderkirkens præstationsfromhed til forståelsesramme for kristusbevægelsens tilblivelse i antikkens jødedom. På baggrund af studier i rabbinske tekster, Dødehavsskrifterne, jødiske pseudepigrafer og apokryfer foreslog Sanders alternativt at beskrive den tidlige jødedom som "pagtsnomisme" (covenantal nomism). Hermed mente han, at Jahves nådige udvælgelse af Israel i form af pagten (pagtsnomisme) altid kommer først og derfor er forudsætning for overholdelsen af toralovens bud (pagtsnomisme, jf. græsk: nomos, lov) - ikke omvendt! Det var derfor en fatal misforståelse, når protestanter beskrev jødedommen som nådesløs præstationsreligiøsitet. Dekalogen indledes jo netop ikke med buddene, men med en påmindelse om, hvad Jahve

11. For eksempler fra forskningshistorien se Ireland (1987), Landry \& May (2000) samt klassiske behandlinger som C.H. Dodd, The Parables of the Kingdom, rev. udg. (London: Fontana Books 1961 [1935]), 26-27 og Joachim Jeremias, Die Gleichnisse Jesus (Göttingen: Vendenhoeck \& Ruprecht, 1947), 34-37, 149-50. Spørgsmålet om lignelsen førlukanske betydning rejser sig ikke mindst, fordi det for denne lignelses vedkommende er relativt tydeligt, at der er tale om en overlevering, som allerede kristusbevægelsen med større eller mindre held forsøgte at uddrage en aktuel mening af. Anderledes kan man næppe forstå den akkumulerede serie af løst sammensatte moraler, som vi finder umiddelbart efter selve lignelsen (vv. 8a/8b-13). 
først har gjort: "Jeg er Herren din Gud, som førte dig ud af Egypten, af trællehuset” (2 Mos 20,2; 5 Mos 5,6). Sanders opsummerede:

\begin{abstract}
The 'pattern' or 'structure' of covenantal nomism is this: (1) God has chosen Israel and (2) given the law. The law implies both (3) God's promise to maintain the election and (4) the requirement to obey. (5) God rewards obedience and punishes transgression. (6) The law provides for means of atonement, and atonement results in (7) maintenance or re-establishment of the covenantal relationship. (8) All those who are maintained in the covenant by obedience, atonement and God's mercy belong to the group which will be saved. An important interpretation of the first and last point is that election and ultimately salvation are considered to be by God's mercy rather than human achievement. ${ }^{12}$
\end{abstract}

I den tidlige jødedom kommer Jahves nåde således både først og sidst. Toraoverholdelsen fungerer derfor ikke som adgangsbillet til at komme ind $i$ pagten med Gud (getting in), men er en metode til at forblive $i$ pagten (staying in). Sanders medgiver, at der kan være enkelte undtagelser i de jødiske tekster ( $\mathrm{f}_{\mathrm{x}} 4$ Ezrasbog), men overordnet set gælder det, at: "in all the literature surveyed, obedience maintains one's position in the covenant, but it does not earn God's grace as such. It simply keeps an individual in the group which is the recipient of God's grace" (ibid., 420; Sanders' kursiv). Mennesker kan ikke fortjene udvælgelsen, men inden for Guds nådessfære kan de arbejde på at blive frelst ved den endelige dom, hvilket dog i sidste ende - uden at dette opfattes som en teologisk selvmodsigelse - altid vil være på baggrund af Guds nåde, dvs. en nådeløn. Dette er basalt set den antikke jødedoms pagtsnomistiske teologi.

12. E.P. Sanders, Paul and Palestinian Judaism: A Comparison of Patterns of Religion (Philadelphia: Fortress 1977), 422; jf. også fx den kortere formulering s. 75. Sanders har, siden bogen udkom, mødt kritik fra forskelligt hold. En jødisk forsker som Jacob Neusner har kritiseret Sanders for med sit begreb om covenantal nomism og siden hen Common Judaism at foretage en alt for generaliserende beskrivelse af de mange teologier i den tidlige jødedom. Neusner talte hellere i flertal om $J u$ daisms, jf. fx Jacob Neusner, William Scott Green \& Ernest S. Frerichs, Judaisms and their Messiahs at the turn of the Christian Era (Cambridge: Cambridge University Press 1987), ix. Endvidere er Sanders blevet kritiseret for at overbetone det doktrinære læreindholds betydning på bekostning af rituelle praksisser samt for at forsvare den tidlige jødedom ud fra dybest set protestantiske begreber om teologisk korrekthed, jf. fx Sanders' understregning af Jahves "nåde" (Jacob Neusner, "Mr. Sanders' Pharisees and Mine: A Response to E.P. Sanders, Jewish Law from Jesus to the Mishnab”, Scottish Journal of Theology 44 (1991), 73-96 (94-95). Sanders har forsvaret sig fornuftigt i fx idem, "Covenantal Nomism Revisited", Jewish Studies Quarterly 16 (2009), 23-55. 
Med henblik på at læse lignelsen i Luk 16,1-8a i lyset af jødisk pagtsnomistisk teologi kan det være en hjælp at reducere Sanders' ovenstående otte momenter til de følgende tre helt basale, der tilsammen danner pagtsnomismens soteriologiske forløb: Først Guds nådige kærlighedshandling mod mennesker i fortiden ("Gave"); dernæst menneskets nutidige svar på gaven i form af livsførelse efter Guds vilje ("Opgave”); og endelig Guds fremtidige evaluering af menneskets varetagelse af opgaven mhp. forkastelse eller frelse ("Dom"). Dette Gave-Opgave-Domforløb er soteriologisk, for så vidt det anviser vejen til frelsen, hvad enten frelsen i den konkrete jødiske tekst tænkes immanent eller transcendent. Forløbet forudsætter naturligvis en negativ udgangssituation (fx slaveriet i Ægypten eller at Jahve var uden folk). Jahve sætter sig imidlertid for at løse dette problem ved at sætte Gave-Opgave-Domforløbet i gang. Det soteriologiske forløbsskema forudsætter således et problem, der skal løses, og består derfor mere fuldstændigt af fire trin: I. Problem, II. Gave, III. Opgave og IV. Dom. Vi kan illustrere den jødiske pagtsnomismes soteriologi på følgende måde:

\begin{tabular}{|l|l|l|l|c|}
\cline { 2 - 5 } \multicolumn{1}{c|}{} & \multicolumn{2}{c|}{ Fortid } & \multicolumn{1}{c|}{ Nutid } & Fremtid \\
\cline { 2 - 5 } \multicolumn{1}{c|}{} & I. Problem & $\begin{array}{c}\text { II. Gave } \\
\text { (getting in })\end{array}$ & $\begin{array}{l}\text { III. Opgave } \\
\text { (staying in })\end{array}$ & IV. Dom \\
\hline $\begin{array}{l}\text { Jødisk } \\
\text { pagtsno- } \\
\text { misme }\end{array}$ & $\begin{array}{l}\text { Jahve } \\
\text { uden folk, } \\
\text { Slaveriet i } \\
\text { Egypten }\end{array}$ & $\begin{array}{l}\text { Udvælgel- } \\
\text { sen, exodus, } \\
\text { pagten, lan- } \\
\text { det, toraen }\end{array}$ & $\begin{array}{l}\text { Overhol- } \\
\text { delse af } \\
\text { toraens bud }\end{array}$ & $\begin{array}{l}\text { Folkets be- } \\
\text { frielse eller } \\
\text { forkastelse, } \\
\text { den eskato- } \\
\text { logiske dom }\end{array}$ \\
\hline
\end{tabular}

Man kan diskutere, hvorvidt denne model er anvendelig også til skitsering af kristusbevægelsens teologier, som de kommer til udtryk i de nytestamentlige skrifter. Sanders afviste selv, at betegnelsen pagtsnomisme skulle være dækkende for Paulus' teologi, eftersom det hos Paulus ifølge Sanders ikke er pagten med det jødiske folk eller toraen, men kristusparticipationen, der er er det nye omdrejningspunkt (ibid., 511-515, 543). Dette rokker imidlertid ikke ved, at selve den soteriologiske grundstruktur (Problem-Gave-Opgave-Dom) er gennemgående og grundlæggende i Paulus' breve, hvilket Sanders da også medgiver (ibid., 515-18, 543). Vi har at gøre med en jødisk pagtssoteriologisk grundstruktur, som også danner teologisk basis i de nytestamentlige tekster inklusive Lukasevangeliet. Den pagt, inden for hvilken det soteriologiske forløb udspiller sig i Det Nye Testamente, er dog ikke først og fremmest Sinajpagten, men den nye pagt, som var forjættet af profeterne, og som nu i tidens fylde blev indstiftet 
af Jahves messias, Jesus Kristus (1 Kor 11,25; 2 Kor 3,6; Mark 14,24; Matt 26,28; Luk 22,20; Hebr 7,22; 8,1-13; 9,15; 10,16.29; 12,24; 13,20; 1 Pet 3,21; jf. Jer 31,31). Men også denne nye pagt abonnerer på en jødisk pagtssoteriologi. Nedenstående skitse illustrerer en række signifikante pagtssoteriologier i Det Nye Testamente: ${ }^{13}$

\begin{tabular}{|c|c|c|c|c|}
\hline & \multicolumn{2}{|c|}{ Fortid } & \multirow{2}{*}{$\begin{array}{c}\text { Nutid } \\
\text { III. Opgave } \\
\text { (staying in) }\end{array}$} & \multirow{2}{*}{$\begin{array}{c}\text { Fremtid } \\
\text { IV. Dom }\end{array}$} \\
\hline & I. Problem & $\begin{array}{l}\text { II. Gave } \\
\text { (getting in) }\end{array}$ & & \\
\hline $\begin{array}{l}\text { Paulus' } \\
\text { pagtsso- } \\
\text { teriologi }\end{array}$ & $\begin{array}{l}\text { Trældom } \\
\text { under synd } \\
\text { og død (Gal } \\
4,8-10 ; \\
\text { Rom 5-8) }\end{array}$ & $\begin{array}{l}\text { Kristi retfærdig- } \\
\text { hed (Rom 3,21- } \\
\text { 26); ånden (Gal } \\
\text { 5,13-26); den nye } \\
\text { pagt }(2 \text { Kor 3,6) }\end{array}$ & $\begin{array}{l}\text { Hellighed (1 } \\
\text { Thess 3,13); } \\
\text { tro virksom } \\
\text { i kærlighed } \\
\text { (Gal 5,6) }\end{array}$ & $\begin{array}{l}\text { Evigt liv/ } \\
\text { Guds rige } \\
\text { eller forta- } \\
\text { belse (Rom } \\
2,6-13 ; 11,22 \\
1 \text { Kor } 6,9-10 \text {; } \\
\text { Gal } 5,21 \text { ) }\end{array}$ \\
\hline $\begin{array}{l}\text { Matthæus- } \\
\text { evangeliets } \\
\text { pagtsso- } \\
\text { teriologi }\end{array}$ & $\begin{array}{l}\text { Det syndige } \\
\text { folk (Matt } \\
1,21)\end{array}$ & $\begin{array}{l}\text { Messias' varsling } \\
\text { af himmerigets } \\
\text { nærhed (Matt } \\
\text { 5,3-12) og den } \\
\text { nye pagt }(26,28) \\
\text { med Guds } \\
\text { nærvær }(1,23 ; \\
18,20 ; 28,20)\end{array}$ & $\begin{array}{l}\text { Retfærdighed, } \\
\text { dvs. livsførelse } \\
\text { efter Guds } \\
\text { vilje (Matt } \\
5,17-20)\end{array}$ & $\begin{array}{l}\text { Dom efter } \\
\text { gerninger, } \\
\text { ikke efter } \\
\text { bekendelse } \\
\text { (Matt 7,15- } \\
27 ; 25)\end{array}$ \\
\hline $\begin{array}{l}\text { Johannes- } \\
\text { evangeliets } \\
\text { pagtsso- } \\
\text { teriologi }\end{array}$ & $\begin{array}{l}\text { "Mørket" } \\
\text { (Joh 1,5; } \\
12,46)\end{array}$ & $\begin{array}{l}\text { Åbenbaringen og } \\
\text { inkarnationen } \\
\text { (Joh } 1,14 ; \\
3,16 a) ; \text { Talsman- } \\
\text { den }(14,16)\end{array}$ & $\begin{array}{l}\text { Tro (Joh } \\
\text { 3,16b); kær- } \\
\text { lighed (Joh } \\
\text { 13,34; 15,12) }\end{array}$ & $\begin{array}{l}\text { Evigt liv el- } \\
\text { ler fortabelse } \\
\text { (Joh } 3,16 \mathrm{c} \text { ) }\end{array}$ \\
\hline $\begin{array}{l}\text { Lukansk } \\
\text { pagtsso- } \\
\text { teriologi } \\
\text { (Luk. og } \\
\text { ApG.) }\end{array}$ & $\begin{array}{l}\text { Det ufor- } \\
\text { løste Israel } \\
(1,68-79) ; \\
\text { social uret- } \\
\text { færdighed } \\
(6,20-26)\end{array}$ & $\begin{array}{l}\text { Kristi opfyldelse } \\
\text { af profetier: Guds } \\
\text { inklusion af for- } \\
\text { tabte, udstødte og } \\
\text { ikke-jøder (Luk } \\
\text { 4,16-30); hel- } \\
\text { ligånden til Guds } \\
\text { folk (ApG 2) }\end{array}$ & $\begin{array}{l}\text { Kristi efterføl- } \\
\text { gelse }(9,57-62 \text {; } \\
14,25-35) ; \\
\text { afkald på } \\
\text { rigdom }(6,20- \\
26 ; 12,13-21)\end{array}$ & $\begin{array}{l}\text { Individuel } \\
\text { dom umid- } \\
\text { delbart efter } \\
\text { døden }(16,19 \text { - } \\
31,23,43) ; \\
\text { eskatologisk } \\
\text { værdiomven- } \\
\text { ding }(6,20- \\
26 ; 14,7-14)\end{array}$ \\
\hline
\end{tabular}

13. Læseren kan selv overveje andre eksempler på nytestamentlig pagtssoteriologi, fx i Mark., Heb. og Åb. Teksthenvisningerne i diagrammet er naturligvis ikke udtømmende for de enkelte former for pagtssoteriologi, men repræsenterer vigtige og repræsentative tekststeder. 
Der er naturligvis store indbyrdes forskelle, fx kristologiske og eskatologiske, mellem de nytestamentlige pagtssoteriologier, men formålet med skemaet ovenfor er at pege på basale lighedstræk. Der kan i eksegesen være en tendens til at overdrive forskellene mellem fx paulinsk og matthæisk soteriologi. Det samme gælder lukansk og matthæisk soteriologi, som vi skal se nedenfor. De idémæssige og terminologiske forskelle er ganske interessante og vigtige, men man må ikke overse, at disse forskelle udtrykkes inden for den samme overordnede pagtssoteriologiske grammatik. Vi skal vende tilbage til pagtssoteriologien og dens betydning for fortolkningen af lignelsen, når vi har identificeret lignelsens plads i den lukanske fortællesammenhæng.

\section{Lignelsen i Lukasevangeliets narrative kontekst}

Lignelsen om den kloge godsforvalter (Luk 16,1-8a) fortælles undervejs i løbet af den lukanske rejseberetning, dvs. på Jesu rejse mellem Galilæa og Jerusalem (9,51-19,27). Afsnittet rummer en lang række lignelser, hvoraf en del er lukansk særstof, fx den aktuelle lignelse. Lignelsen følger umiddelbart efter de tre lignelser om hhv. det bortkomne får, den bortkomne mønt og den bortkomne søn i kap. 15 og skal læses i umiddelbar sammenhæng med sidstnævnte. Hos Lukas er fremstillingens rækkefølge på ingen måde tilfældig, sådan som det understreges i evangelieskriftets indledning ("Eftersom mange andre har søgt at give en fremstilling ... , har også jeg besluttet nøje at gennemgå alt forfra og nedskrive det for dig i rækkefølge [ $\varkappa_{\theta} \theta \xi \tilde{\eta}$ ऽ] højtærede Theofilus"; 1,1-3). Forbindelsen til kap. 15 ses allerede af lignelsens indledning, der ikke etablerer en ny situation, men videre-

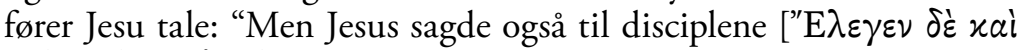

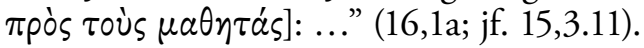

Den amerikanske ekseget John R. Donahue har særligt understreget lignelsens forbindelse til kap. 15. Han betragter således lignelsen om godsforvalteren som en form for dublet til "Den fortabte søn" og opregner en række paralleller de to lignelser imellem: Begge begynder

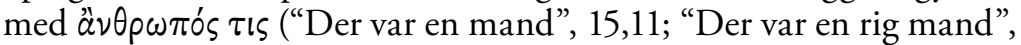
16,1 ; jf. 16,19), og begge slutter med, at denne mand fører ordet i direkte tale $(15,32 ; 16,8)$. Undervejs beskrives den aktør, hvis skæbne er på spil - hhv. den yngste søn og godsforvalteren - som en ødeland, oven i købet med næsten identiske græske vendinger ("Der øds-

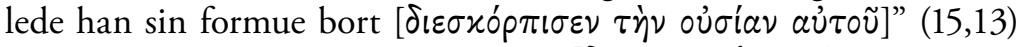

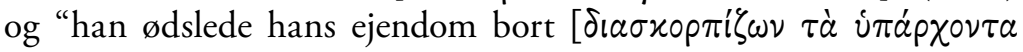


aป่นoũ]" $(16,1)$. Endelig er begge slutninger åbne, hævder Donahue, eftersom læseren hverken hører, om storebroderen går med ind til festen, eller om godsforvalteren bliver reintegreret i den rige mands tjeneste, selvom sidstnævnte må siges at være antydet. ${ }^{14}$ For Donahue tyder de mange paralleller på, at der grundlæggende er tale om to udgaver af den samme lignelse. Lignelserne handler om hhv. den nådige fader og den rige mand, der kaster sin kærlighed på det umoralske menneske. Pagtssoteriologisk formuleret handler lignelserne således om getting in, dvs. om mennesker, der ufortjent og nådigt modtages i Guds kærlighed. De går fra "I. Problem" til "II. Gave" i det pagtssoteriologiske forløb.

\section{Lignelsen som fortsættelse af "Den fortabte søn”}

Donahues fortolkning er øjenåbnende i kraft af dens understregning af sammenhængen med "Den fortabte søn". Imidlertid overser Donahue noget helt afgørende for fortolkningen af lignelsen om godsforvalteren, nemlig at dens primæradressater ikke er de samme som i "Den fortabte søn". Lignelserne i kap. 15, herunder "Den fortabte søn", handler ganske rigtigt om getting in, eftersom de er henvendt til dem udenfor ("farisæerne og de skriftkloge") og skal forklare, hvordan Gud tager imod toldere og syndere (15,1-3). ${ }^{15}$ Men lignelsen om den uærlige godsforvalter er som ovenfor anført først og fremmest stilet til disciplene ("Men Jesus sagde også til disciplene"; 16,1a), dvs. til dem, der allerede er indenfor. ${ }^{16}$ Lignelsen skal derfor belære parænetisk om, hvordan de, der er indenfor, forbliver indenfor (staying in). Lignelsen kan således ikke opfattes som en dublet, men i pagtssoteriologisk forstand som en fortsættelse af "Den fortabte søn", eftersom den ikke blot stopper med "II. Gaven" (getting in), men går videre i det pagtssoteriologiske skema og desuden beretter om "III. Opgave" og "IV. Dom" (staying in). "Den fortabte søn” er som nævnt en ufærdig lignelse med åben slutning. Ofte påpeges det, at læseren efterlades uvidende om, hvorvidt den

14. For yderligere, men efter min mening mindre signifikante paralleller se John R. Donahue, S.J., The Gospel in Parable: Metaphor, Narrative, and Theology in the Synoptic Gospels (Philadelphia: Fortress 1988), 167-68.

15. At lignelserne i kap. 15 alle, hvad angår fåret, mønten og den yngste søn, følger et hjem-ude-hjem-skema, ændrer ikke ved, at fortællerammen i 15,1-3 bestemmer det overordnede tema i lignelserne som getting in.

16. Senere i teksten viser det sig, at "de pengeglade farisæere" også har lyttet med $(16,14)$, men lignelsens primæradressater er stadigvæk disciplene. 
ældste søn lader sig overtale til at gå med ind til festen. Men ikke mindre vigtigt er det $i$ en pagtssoteriologisk sammenhæng, at lignelsen ikke giver noget svar på, hvordan den yngste søn efterfølgende responderer på den gave, som han har modtaget af faderen $\mathrm{i}$ form af den overdådige velkomst. Beder han næste morgen efter festen sin fader om et nyt arveforskud, så han kan tage på langfart igen, eller erkender han, at der i gaven ligger en opgave, nemlig den at imitere faderens barmhjertighed ved selv at være barmhjertig og give gaven videre til næsten (jf. fx Luk 6,36)? Lignelsen om godsforvalteren behandler netop dette spørgsmål, som jo ikke er mindre vigtigt i en lukansk sammenhæng, hvor disciplenes efterfølgelse af Kristus ofte understreges. I kap. 14 finder vi således en lignende narrativ struktur: Lignelsen om det store festmåltid (vv. 15-24) handler om getting in, hvorefter talen om efterfølgelsens pris tematiserer staying in (vv. 25-35). Vi skal nu se, hvordan lignelsen narrativt gennemløber det pagtssoteriologiske skema.

\section{Gaven: At vare forvalter over den rige mands gods $(16,1 a)$}

Lignelsen tager udgangspunkt i en antik socio-økonomisk virkelighed og handler om en rig mand og hans godsforvalter, formentlig en slave - en konstellation som også kendes fra andre lignelser i den

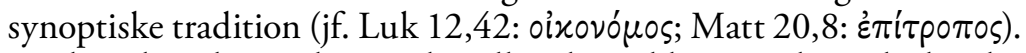
Da lignelsen begynder, er der allerede etableret en hierarkisk relation mellem de to hovedpersoner. Lignelsen beretter således ikke om, hvorledes forpagteren har fået sin stilling, eftersom fortællingen om getting in (fra I. Problem til II. Gave) jo allerede er fortalt i den foregående lignelse om den fortabte søn. Men det er naturligvis som i det øvrige romersk-imperiale samfund patronen, der har udpeget klienten. I pagtssoteriologisk forstand forudsætter lignelsen om forvalteren "II. Gaven", som her er repræsenteret ved forvalterens stilling og det gods, han forvalter.

\section{Opgaven: Negativ forvaltning $(16,1 b)$}

Spørgsmålet er nu, hvordan forvalteren bruger sin stilling, dvs. hvordan han løser den opgave, der følger med gaven. Lignelsen beretter om dette moment i det pagtssoteriologiske skema (III. Opgaven) i to omgange. Først løses opgaven negativt $(16,1 b)$, dernæst positivt $(16,4-$ 7; se nedenfor). Den første, negative forvaltning udgør den første af flere overraskelser på den ellers hverdagslige scene. Forvalteren viser sig åbenbart at være uduelig, siden han forspilder den rige mands 


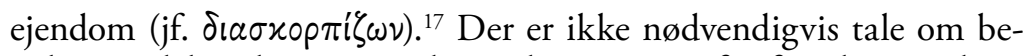
vidst svindel, sådan som aarhusteologerne ovenfor forudsatte i deres udlægninger, men blot om urentabel forvaltning. Der er ligesom i "Den fortabte søn" tale om en negativ ødselhed $(15,13)$, der hverken gavner den rige mand/faderen, ødelanden selv eller næsten.

\section{Dommen: Negativ dom (16,2-3)}

Den rige mands reaktion følger, så snart han får nys om den dårlige forvaltning. $\mathrm{Nu}$ foranstaltes regnskabets time, og den rige mand sætter sig for at fratage forvalteren embedet. I pagtssoteriologisk forstand mislykkes forvalteren i første omgang med staying in. Hans negative forvaltning (III. Opgave) afstedkommer en varslet afskedigelse (IV. Dom). Men hermed slutter lignelsen ikke. I lyset af den forestående negative dom vækkes forvalterens desperation, og han begynder at overveje, hvordan han kan undgå sin skæbne. Resultatet bliver, at lignelsen i det følgende gennemspiller staying in-forløbet (III. Opgave og IV. Dom) i en ny og positiv udgave.

\section{Opgaven: Positiv forvaltning $(16,4-7)$}

Dette er lignelsens næste twist. Den uduelige forvalter får en lys idé

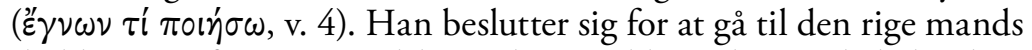
skyldnere en for en og nedskrive deres gæld. På den måde håber han på at gøre sig interessant for dem, så de til gengæld kan dæmme op for hans sociale deroute, når han bliver sat fra bestillingen. Muligvis er han i færd med at søge om optagelse som klient i husstanden hos disse gældstyngede debitorer, der også selv er klienter hos den rige

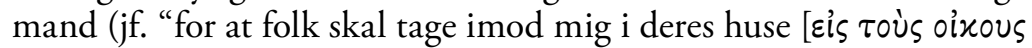

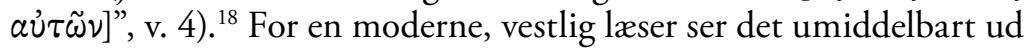
til, at forvalteren giver sig i kast med at svindle med den rige mands lånekontrakter - og det var også sådan de fire "store" aarhusteologer forstod lignelsens videre forløb - men J.D.M. Derrett og Joseph A. Fitzmyer har foreslået, at forvalteren ved at nedskrive gælden blot ser bort fra sin egen kommission, således at gælden til den rige mand egentlig forbliver den samme. Dette skulle svare til jødisk praksis for

17. Det har været foreslået, at $\delta\left\llcorner\varepsilon \beta \lambda \eta^{\prime} \theta \eta\right.$ (aor. af $\delta\llcorner\alpha \beta \alpha \dot{\alpha} \lambda \omega$ ) skal forstås sådan, at der er tale om falske beskyldninger mod forvalteren. Se fx John S. Kloppenborg, "The Dishonoured Master (Luke 16,1-8a)", Biblica 70 (1989), 487-88 og Mary Ann Beavis, "Ancient Slavery as an Interpretive Context for the New Testament Servant Parables with Special Reference to the Unjust Steward (Luke 16:1-8)", JBL 111 (1992), 48-49. Men i så fald må det undre, at forvalteren ikke prøver på at forsvare sig, hvorfor jeg her følger flertallet af fortolkere, der oversætter $\delta\left\llcorner\varepsilon \beta \lambda \eta^{\prime} \theta \eta\right.$ på samme som DO92: "fik ... underhånden at vide".

18. Denne pointe muliggøres yderligere med brugen af det refleksive $\dot{\varepsilon} \alpha \tau \tau \tilde{\omega} \nu$ i bl.a. Codex Sinaiticus og Vaticanus: "i deres egne huse". 
låntagning, hvor der ikke tages renter, men til gengæld et fast gebyr, som forvalteren altså her vælger at se bort fra (jf. fx 3 Mos 25,36-37; 5 Mos 23,20-21; Josefus, Antiquitates Judaicae 18.6.3 og den sene Mishnatraktat Bava Metzia). ${ }^{19}$ Andre fortolkere har forsøgt at placere lignelsen i en romersk kontekst. Fx gør John K. Goodrich opmærksom på, at jordejere i Romerriget i situationer, hvor deres klienter var særligt pressede økonomisk, kunne foranstalte en form for gældssanering, der var i alles interesse. I lignelsen her eftergiver forvalteren gæld til de pressede debitorer på den rige mands vegne, hvilket den rige mand ender med at se det kloge og fornuftige $i^{20}{ }^{20}$ Hvad enten vi godtager Derretts og Fitzmyers (palæstinajødiske) eller Goodrichs (romerske) rekonstruktion af de socio-økonomiske forhold, bliver pointen den, at forvalteren i sin kamp for at redde sig selv nu ikke længere negativt forspilder den rige mands ejendom $(16,1 b)$, men forvalter sin embedsopgave positivt ved at lette situationen for de gældbundne og dermed fastholde dem som nyttige klienter for den rige mand. Forvalteren kommer således til at virkeliggøre et lukansk ideal om positiv ødselhed i forhold til socialt udsatte (fx 12,33; 16,19-31). Derfor evalueres godsforvalterens redningsplan positivt, sådan som det kommer frem i den rige mands efterfølgende reaktion.

\section{Dommen: Positiv dom $(16,8 a)$}

Den rige mands endelige dom over forvalteren er lignelsens tredje og sidste twist: "Og herren roste den uretfærdige forvalter, fordi han hav-

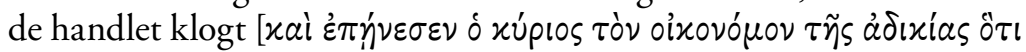

19. J.D.M. Derrett, "Fresh Light on St Luke xvi: I. The Parable of the Unjust Steward", New Testament Studies 7 (1960-61), 198-219; Joseph A. Fitzmyer, S.J.. "The Story of the Dishonest Manager (Luke 16:1-13)", Theological Studies 25 (1964), 23-42; idem, The Gospel according to Luke (X-XXIV), The Anchor Bible 28a (New York: Doubleday 1985), 1097-98, 1101. John S. Kloppenborg har bl.a. på grundlag af antikke papyrusmanuskripter med lånekontrakter udtrykt en delvist berettiget kritik af denne fortolkning. Den er relativt svagt dokumenteret i samtidige palæstinajødiske og græsk-romerske kilder (Kloppenborg 1989, 492-93). Kloppenborg vil i stedet forstå den rige mand som en pater familias, der i lignelsens forløb først vanæres offentligt, da det bliver kendt, at han ikke kan styre forvalteren i sin husstand, og siden bedrages af forvalteren for betragtelige midler. Lignelsen slutter imidlertid med en overraskende omvending af konventionelle ære/skam-begreber, da den rige mand i stedet for at straffe forvalteren afstår fra at genoprette sin egen ære i gængs forstand. Kloppenborgs fortolkning minder om Donahues ved at fokusere på den rige mands ukonventionelle handlemåde svarende til faderens ageren $\mathrm{i}$ "Den fortabte søn" (getting in) frem for det parænetiske aspekt (staying in). Se min kritik af Donahue ovenfor.

20. John K. Goodrich, "Voluntary Debt Remission and the Parable of the Unjust Steward (Luke 16:1-13)", JBL 131 (2012), 547-66. Forvalterens spørgsmål til de enkelte debitorer ("Hvor meget skylder du min herre?", v. 5) tyder på, at det er herrens og ikke forvalterens udlån, der delvist eftergives i lignelsen. 


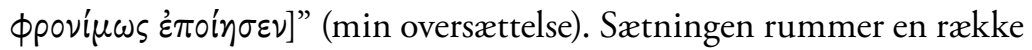
eksegetiske problemer, hvoraf de tre vigtigste skal behandles her. For det første må man spørge, hvem "herren", der roser, er. DO92 skriver "Herren" med stort, hvorved det forudsættes, at det er Jesus, der som lignelsens fortæller nu vurderer en af de fortalte hovedpersoner positivt, nemlig godsforvalteren (jf. Jeremias 1947, 34-37). De fleste eksegeter inkluderer imidlertid v. 8a i selve lignelsen, således at sætningen udgør lignelsens afslutning. Herren, der roser godsforvalteren, er ifølge denne opfattelse den samme som den rige mand i v. 1 samt i vv. 3 og 5, hvor han netop kaldes "herre" (jf. Fitzmyer 1985, 1096-1101). ${ }^{21}$ Spørgsmålet er afgørende for en rekonstruktion af lignelsen i en evt. førlukansk udgave, men i den lukanske sammenhæng, som vi opererer i her, er det mindre vigtigt. I Lukas' narrative sammenhæng kan det netop være en pointe, at teksten er tvetydig. Dermed opstår en form for metalepse (dvs. et sammenfald mellem fortalt univers og fortælleunivers), således at der åbnes for en identifikation af den rige mand i lignelsen ("herren") og Jesus, der fortæller lignelsen ("Herren"). Lignelsen hører således ikke entydigt op, men går gradvist i løbet af v. 8 over i en udlægning af lignelsen, der fortsætter til og med v. $13 .{ }^{22}$ At godsforvalteren roses, står under alle omstændigheder ved magt, uanset hvem det er, der udtrykker den.

Og dog. Det andet eksegetiske problem drejer sig om, hvorvidt rosen i virkeligheden skal forstås ironisk, hvilket en del fortolkere har foreslået (se Ireland 1989, 305-7). Dermed undgås den uantagelige konklusion, at lignelsen opfordrer til at følge et dårligt eksempel - forudsat at man altså forstår godsforvalterens redningsplan som negativt beskrevet, hvilket jeg ovenfor allerede har betvivlet. Der er imidlertid ikke noget i konteksten, der tyder på ironi, hvad angår rosen. Den udtrykker en entydigt positiv dom fra herrens side. Til gengæld må der være tale om ironi i lignelsens karakteristik af rosens

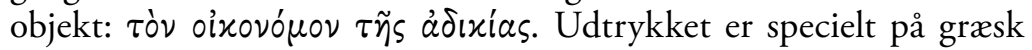
og skal nok forstås som en semitisme, således at genitiven fungerer adjektivisk. Oversættelsen bliver dermed "den uærlige godsforvalter" (jf. DO92) eller bedre: "den uretfærdige godsforvalter". ${ }^{23}$ Men hvor-

21. Codex Bezae Cantabrigiensis (D) understøtter denne forståelse, da overgangen fra lignelse til fortolkning her er tydeligt markeret med ordene "Derfor siger jeg jer

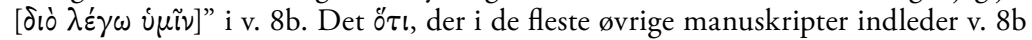
skal sikkert fortstås på samme måde, således at Jesus i v. $8 \mathrm{~b}$ udfolder den begrundelse for rosen, som herren i lignelsen selv giver i v. $8 \mathrm{a}$.

22. Ryan S. Schellenberg, "Which Master? Whose Steward? Metalepsis and Lordship in the Parable of the Prudent Steward (Lk. 16.1-13)", JSNT 30 (2008), 263-88.

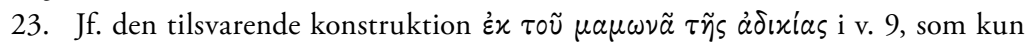
kan forstås adjektivisk svarende til $\dot{\varepsilon} \nu \tau \tilde{\omega} \alpha^{\alpha} \delta^{\prime}(x \omega) \mu \alpha \mu \omega \nu \tilde{a}$ i v. 11. Se også 18,6. 
dan kan dette så være ironisk? 'A $\delta$ เxí ("uretfærdighed", "synd”) er $i$ en jødisk pagtsnomistisk sammenhæng en helt central term, eftersom den står som modsætning til den "retfærdighed" (dvs. livsførelse efter Guds vilje), som er opgaven for ethvert menneske, der står i pagten (jf. fx Luk 1,6). Lukas udfordrer imidlertid gang på gang en konventionel opfattelse af, hvad retfærdighed er, og hvem der er hhv. retfærdig og uretfærdig, fx i to af de lignelser, der forekommer mod rejseberetningens slutning. I lignelsen om enken og den uretfærdige dommer optræder en uretfærdig dommer ( $\dot{0} x p i \tau \dot{\eta} s \tau \tilde{\eta} s$ ádıxias; 18,6), der skønt han beskrives som "uretfærdig", rent faktisk gør det retfærdige overfor den nødstedte enke (18,1-8). I lignelsen om farisæeren og tolderen byttes rollerne tilsvarende om: "Til nogle,

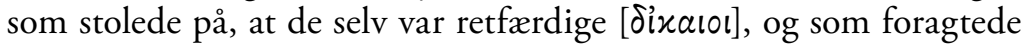
alle andre, fortalte Jesus denne lignelse" $(18,9)$. Her var det som bekendt ikke farisæeren, men tolderen, "der gik hjem som retfærdig

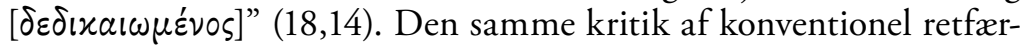
dighed lyder i kap. 16 umiddelbart efter vores lignelse: "I stiller jer

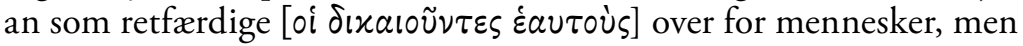
Gud kender jeres hjerte" (16,15; jf. 7,36-49; 15,7; 2 Kor 12,13). I Lukas' fortællesammenhæng forekommer det således plausibelt, at også udtrykket "den uretfærdige godsforvalter" skal forstås ironisk. Ligesom farisæerne fremstår som retfærdige, men i virkeligheden ikke er det, beskrives forvalteren ironisk som uretfærdig, skønt han ud fra lukanske standarder rent faktisk handler retfærdigt til sin herres ros. Forvalteren udfører den rige mands vilje ved at hjælpe gældstyngede med de midler, han er blevet betroet (jf. 12,32-34). Den "uretfærdige" godsforvalter får ros, fordi han, skønt han til at begynde med var uduelig til sin forvalteropgave, med dommen for øje endte med at løse sin opgave og handle i Sletteprædikenens ånd: "Vær barmhjertige, som jeres fader er barmhjertig" $(6,36)$. Den rige mand er således mod lignelsens slutning blevet talerør for en lukansk efterfølgelsesteologi, og hans stemme er, som vi har nævnt, ikke til at skelne fra Jesu egen. ${ }^{24}$

Med denne fortolkning af à $\delta$ เxía som et ironisk udtryk har jeg også så at sige besvaret det tredje eksegetiske problem: Hvorfor siges

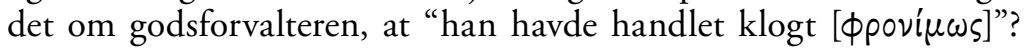
Svaret må som sagt være, at godsforvalteren i fortællingens forløb, selvom han indledningsvis er uduelig, under indvarslingen af regnskabets time kommer til at handle med det betroede gods efter den

24. For en lignende fortolkning af ảঠıxía som ironisk se L. John Topel, S.J., "On the Injustice of the Unjust Steward: Lk 16:1-13”, Catholic Biblical Quarterly 37 (1975), 216-227; jf. Fritz Maass, "Das Gleichnis vom ungerechten Haushalter, Lukas 16,1-8”, Theologia Viatorum 8 (1962), 173-84. 
rige mand vilje. Hans klogskab er således ikke intellektuel, men er en praktisk forstandighed, der sikrer ham den rige mands ros. Forvalteren i lignelsen bliver svaret på Jesu spørgsmål til disciplene $\mathrm{i}$ Luk 12:42-43: "Hvem er da den tro og kloge forvalter [ $\delta$ i $\pi$ lò̀s

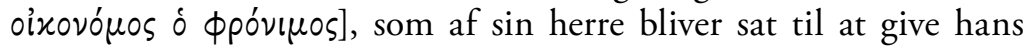
tjenestefolk mad i rette tid? Salig den tjener, som hans herre finder i færd med at gøre det, når han kommer!"25 Ifølge Lukas er dette netop, hvad godsforvalteren afslutningsvis er i færd med. Inden for pagtens transitive økonomi løses opgaven ifølge Lukas ikke ved at holde det betroede gods for sig selv som den rige, men tåbelige bonde i lignelsen i 12,13-21 eller som den rige mand over for den fattige Lazarus senere i kap. 16 (16,19-31), og heller ikke ved at forspilde det, sådan som forvalteren gør til at begynde med, men ved at dele godset med andre, sådan som han gør til sidst - i øvrigt svarende til de to gode tjeneres investeringer i lignelsen om de betroede pund (19,11-27). Lignelsen om den kloge godsforvalter besvarer således et centralt spørgsmål, som "Den fortabte søn” efterlader ubesvaret: Når Gud har taget et menneske ind til sig (fra I. Problem til II. Gave, getting in), hvordan skal mennesket så svare på dette? Den kloge godsforvalter er i den forbindelse et parænetisk eksempel til efterfølgelse for disciplene (fra III. Opgave til IV. Dom, staying in). I det pagtssoteriologiske skema ser denne forståelse af lignelsen ud som skitseret på næste side. ${ }^{26}$

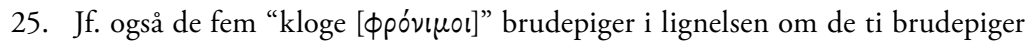
i Matt 25,1-13.

26. Matthæus' lignelse om den gældbundne tjener (Matt 18,21-35) er medtaget i skemaet som et eksempel på en lignelse, der eksplicit rummer hele det pagtssoteriologiske narrativ (Problem-Gave-Opgave-Dom). Den gældsramte tjener (I. Problem) modtager en enorm eftergivelse fra kongen (II. Gave), men indser ikke, at denne gave rummer en tilsvarende opgave i forhold til næsten (III. Opgave), hvorfor han ryger i gældsfængsel (IV. Dom). I denne lignelse falder den endelige dom negativt ud, hvor det modsatte gør sig gældende i "Den kloge godsforvalter". 


\begin{tabular}{|c|c|c|c|c|}
\hline & \multicolumn{2}{|c|}{ Fortid } & \multirow{2}{*}{\begin{tabular}{|c} 
Nutid \\
$\begin{array}{c}\text { III. Opgave } \\
\text { staying in })\end{array}$
\end{tabular}} & \multirow{2}{*}{$\begin{array}{l}\text { Fremtid } \\
\text { IV. Dom }\end{array}$} \\
\hline & I. Problem & $\begin{array}{l}\text { II. Gave } \\
\text { (getting in) }\end{array}$ & & \\
\hline $\begin{array}{l}\text { Den fortabte } \\
\text { søn (Luk } \\
15,11-32)\end{array}$ & $\begin{array}{l}\text { Den bort- } \\
\text { komne søn } \\
\text { (vv. 11-19) }\end{array}$ & $\begin{array}{l}\text { Den fundne } \\
\text { søn (vv. } \\
20-24)^{\mathrm{a}}\end{array}$ & - & - \\
\hline $\begin{array}{l}\text { Den kloge } \\
\text { godsforvalter } \\
\text { (Luk 16,1-8a) }\end{array}$ & - & $\begin{array}{l}\text { Forvalterens } \\
\text { embede, det } \\
\text { forvaltede } \\
\text { gods (v. 1a) }\end{array}$ & $\begin{array}{l}\text { Negativ } \\
\text { forvaltning: } \\
\text { forvalterens } \\
\text { uduelighed } \\
\text { (vv. 1b-3) } \\
\text { Positiv for- } \\
\text { valtning: } \\
\text { forvalterens } \\
\text { gældsef- } \\
\text { tergivelse } \\
\text { (vv. 4-7) }\end{array}$ & $\begin{array}{l}\text { Negativ } \\
\text { dom: den } \\
\text { bebudede } \\
\text { afskedigelse } \\
\text { (vv. 2-3) } \\
\text { Positiv dom: } \\
\text { herrens ros } \\
\text { af forvalte- } \\
\text { ren (v. 8a) }\end{array}$ \\
\hline $\begin{array}{l}\text { Den gæld- } \\
\text { bundne } \\
\text { tjener (Matt } \\
18,21-35)\end{array}$ & $\begin{array}{l}\text { Tjenerens } \\
\text { gæld til } \\
\text { kongen } \\
\text { på } 10.000 \\
\text { talenter (vv. } \\
\text { 23-26) }\end{array}$ & $\begin{array}{l}\text { Kongens } \\
\text { eftergivelse } \\
\text { af tjenerens } \\
\text { gæld (v. 27) }\end{array}$ & $\begin{array}{l}\text { Tjenerens } \\
\text { krav på } 100 \\
\text { denarer fra } \\
\text { medtjeneren } \\
\text { (vv. 28-30) }\end{array}$ & $\begin{array}{l}\text { Tjenerens } \\
\text { fængsling } \\
\text { (vv. 31-35) }\end{array}$ \\
\hline
\end{tabular}

a) $V_{v}$. 25-32 om den ældste søn er i denne sammenhæng en sidehistorie. Den yngste søns opgave (staying in) kan ganske vist være at angre og blive forsonet med storebroderen (jf. Luk 17,3), men dette tematiseres ikke i lignelsen.

\section{Lignelsens fortolkning i 16,8b-13}

Skønt selve lignelsen ovenfor har været omdrejningspunktet for denne artikel, vil jeg afslutningsvis knytte nogle enkelte kommentarer til de udlægninger af lignelsen, som kommer til udtryk i v. 8b-13. De svarer nemlig godt til den pagtssoteriologiske fortolkning af lignelsen, jeg har præsenteret ovenfor. Versene består af både særstof (vv. 8b-12) og Q-stof (v. 13; jf. Matt 6,24), hvilket tyder på, at der er tale om en sammenredigering af Jesuslogier, der oprindeligt har hørt hjemme i forskellige kontekster. C.H. Dodd beskrev ligefrem versene her som små skitser til tre forskellige mulige prædikener over teksten (Dodd 1961 [1935], 26). En sådan praksis med at akkumulere fortolkninger til en lignelse kendes i øvrigt fra de antikke skoleøvelser (progymnas- 
mata), hvor det hørte med til undervisningen i fabler, at eleven skulle formulere en eller flere moraler til historien. ${ }^{27}$

Logierne i 16,8b-13 er bundet sammen af stikord vedrørende klog-

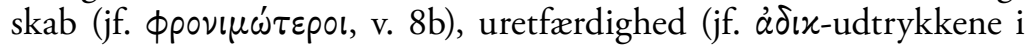
vv. 9-10), troskab (jf. $\pi เ \sigma \tau$-udtrykkene i vv. 10-12) og ret omgang med penge ( $\mu \alpha \mu \omega \nu \tilde{a} \varsigma$ [mammon] i vv. 9, 11 og 13). I Lukas' fortællesammenhæng danner vv. 8b-13 således bro mellem på den ene side "Lignelsen om den kloge godsforvalter" og på den anden side de følgende perikoper i kap. 16 om penge og rigdom, hhv. om "de pengeglade farisæere" (v. 14) og "Lignelsen om den rige mand og Lazarus" (vv. 19-31). Som kommentar til "Lignelsen om den kloge godsforvalter" understreger vv. 8b-13 lignelsens parænetiske karakter (staying in) og godsforvalterens rolle som eksempel til efterfølgelse. I lignelsen er han en af "denne verdens børn", men "lysets børn” kan lære af hans kløgtige selvopholdelsesdrift (v. 8b). Og ligesom forvalteren benyttede sig af en positiv ødselhed for at blive modtaget i skyldnernes huse og blev rost af sin herre for det (v. 4), skal disciplene ødsle med "uretfærdig" mammon indtil den "slipper op", for at de kan blive taget imod "i de evige boliger" (v. 9). Godsforvalteren tjente sin herre ved at give afkald på mammon, og sådan skal også disciplene tjene Gud og ikke mammon (v.13) - i øvrigt modsat den rige mand i den følgende lignelse, der ignorerer den fattige Lazarus og dermed fremstår som et advarende eksempel (vv. 19-31). I den lukanske fortællesammenhæng støtter udlægningerne i vv. 8b-13 og i det øvrige kap. 16 således en forståelse af den kloge og "uretfærdige" forvalter som forbillede for disciplene, ikke mindst i pengesager. Den kloge godsforvalter er for Lukas en sand retfærdig modsat farisæerne, hvis retfærdighed kun er på skrømt (v. 15).

\section{Konklusion og perspektivering}

Den ovenstående læsning af lignelsen om den kloge godsforvalter (Luk 16,1-8a) understreger lignelsens nære sammenhæng med den foregående lignelse om den fortabte søn i kap. 15. Samtidig danner lignelsen bro til temaet om rigdom og fattigdom senere i kap. 16 (vv. 14-31), hvilket forstærkes af de fortolkninger, som følger umiddelbart efter selve lignelsen (vv. 8b-13). Lignelsen om den kloge godsforvalter

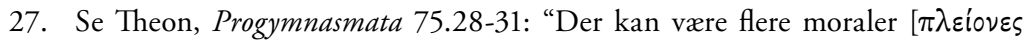
$\dot{\varepsilon} \pi \hat{i}$ ○ $\left.\gamma_{0} \mathrm{l}\right]$ til den ene fabel, når vi tager udgangspunkt i enhver af fabelens handlinger" (Michel Patillon \& Giancarlo Bolognesi, Aelius Théon, Progymnasmata, Collection Budé [Paris: Les Belles Lettres 1997], 35; min oversættelse). 
er imidlertid ikke en dublet ift. "Den fortabte søn”, men en fortsættelse, eftersom "Den fortabte søn” er henvendt til udenforstående om getting in, mens "Den kloge godsforvalter" er henvendt til insidere og behandler staying in i det pagtssoteriologiske skema. Med lignelsens vægt på staying in er Lukas således her i kap. 16 vendt tilbage til temaet om efterfølgelse fra kap. 14.

"Den fortabte søn" kan derfor ikke læses for sig som et udtømmende udtryk for Lukas' pagtssoteriologiske teologi; dertil må den "Den kloge godsforvalter" inddrages. Den kloge forvalter modtager ligesom den fortabte søn en "Gave" (sit embede, det forvaltede gods). Historien gennemspiller nu "Opgaven" og "Dommen" i to omgange, først en negativ, hvor forvalteren mislykkes med opgaven og stilles en negativ dom i udsigt (vv. 1b-3), dernæst en positiv, hvor han lykkes ved at sanere debitorernes dybe gæld og modtager sin herres ros (vv. 4-8a). Samlet set rummer "Den fortabte søn" og "Den kloge godsforvalter” således det fulde pagtssoteriologiske narrativ i en udgave, der ender positivt. Denne pagtssoteriologiske teologi vokser ud af den tidlige jødedoms pagtsnomisme og er grundlæggende for de nytestamentlige tekster. Det er en teologi, der ligger et godt stykke fra den lutherske og dialektiske teologi, som var de fire "store" aarhusteologers receptionsfilter, men der er tale om et fortolkningsfilter, der giver mening i Lukas' narrative og religionshistoriske kontekst. Og sådan er det med lignelserne. De er didaktiske fortællinger, som i kraft af deres metaforiske og indirekte meddelelse inviterer tilhøreren til at bidrage til meningsproduktionen. 